\title{
ЗООЛОГИЯ
}

УДК 599.426-153.125.7(470.54)

doi: $10.17223 / 19988591 / 35 / 6$

\section{О.Р. Гизуллина, Е.М. Первушина}

Институт экологии растений и животных УрО РАН, г. Екатеринбург, Россия

\section{Определение фрагментов насекомых в питании двухцветного кожана в Среднем Зауралье}

Работа выполнена при поддержке гранта РФФИ в рамках научного проекта № 12-04-31257.

\begin{abstract}
Приведены описание и фотографии для определения фрагментов насекомых, поедаемых Vespertilio murinus L. (Chiroptera). Впервые на территории равнинного Среднего Зауралья изучен рачион этого вида. В составе рациона нами отмечень насекомье 8 отрядов: Diptera (Nematocera, Brachycera), Trichoptera, Hymenoptera (Ichneumonidae), Homoptera (Cicadinea, Aphidina), Coleoptera, Lepidoptera, Hemiptera, Neuroptera (Hemerobiidae, Chrysopidae) и представители кл. Arachnida (Acari). Самые высокие частоты встречаемости и обилия отмечены для Diptera (Nematocera), Coleoptera и Hoторtera (Cicadinea). Выявленный состав рациона Vespertilio murinus L. сходен с рационом вида на территории Европы и России, но имеются различия в численном соотночении пищевых групп.
\end{abstract}

Ключевые слова: рукокрылье; Vespertilio murinus; питание.

\section{Введение}

Летучие мыши входят в состав большинства лесных биоценозов Палеарктики, поедая в массе сумеречных и ночных насекомых. Изучение питания этих насекомоядных млекопитающих представляет интерес не только с научной, но и с практической точки зрения. Они уничтожают большое количество насекомых - вредителей лесного и сельского хозяйства, а также переносчиков опасных инфекционных заболеваний человека и домашних животных, таких как малярия, филяриозы и различные комариные энцефалиты [1]. За рубежом имеется достаточное количество исследовательских работ в этой области [2-7]. Но на значительной территории России таких исследований мало [8-11], а для Урала они единичны [12]. Поэтому нами предприняты исследования структуры рациона фонового и высокопластичного на Среднем Урале вида летучих мышей (Chiroptera, Vespertilionidae) - двухцветного кожана Vespertilio murinus Linnaeus, 1758. Исследования проведены с помощью анализа остатков насекомых в экскрементах животных - метод, который является доступным и общепризнанным в мировой практике 
для изучения питания летучих мышей, наряду с современными методами секвенирования фекальных образцов [6-7]. К тому же, с помощью данного метода, используя современную цифровую технику, возможно создание атласа фотографий для определения остатков поедаемых насекомых. Цель настоящей работы - изучить структуру рациона двухцветного кожана и составить атлас-определитель фрагментов поедаемых этим видом насекомых с помощью цифрового стереомикроскопа.

\section{Материалы и методики исследования}

Сбор материала для исследований проводили на территории с. Скородумское (Ирбитский р-н Свердловской обл., 57³6' с.ш. и 6252' в.д.) 11 и 16 июля 2012 г. Это таежные районы Западно-Сибирской равнины, примыкающие на востоке к макросклону Среднего Урала (равнинное Среднее Зауралье). Около населенного пункта протекают небольшие реки (ширина около 30 м) - Бобровка и Ирбитка. Село граничит с одной стороны со значительными по площади массивами леса, с другой стороны с сельскохозяйственными угодьями. Этот район расположен на границе подзоны южной тайги равнинного Среднего Зауралья. К селу примыкают участки темнохвойного леса с участием сосны, ели, пихты и незначительной примесью лиственных пород осины, березы, липы, рябины. Луговые сообщества представлены злаковым разнотравьем. В пойме луга чередуются с древесно-кустарниковыми сообществами, в которых эдификаторами являются черемуха, ольха и хмель [13]. В самом селе большое количество садовокультурных растений, в том числе деревьев и кустарников (тополь, яблоня, вишня, калина, рябина, сирень и т.д.).

Летучих мышей, отловленных паутинными сетями с 3 часов ночи после длительного ночного кормления, помещали в мешочки из ткани и держали в них на протяжении 12 часов, затем выпускали. Оставленные животными экскременты просушивали и упаковывали в бумажные пакеты для длительного хранения. В лаборатории нами из каждого пакета случайно отбирались 5-10 экскрементов близкого размера и формы (выборка). Образцы перед анализом опускали в мыльный раствор не менее чем на 24 ч, чтобы очистить их от загрязнений и удалить покрывающую оболочку. Каждый фекальный шарик (проба) перемещался на предметное стекло в каплю глицерина. Содержащиеся в нем остатки членистоногих равномерно распределяли по поверхности

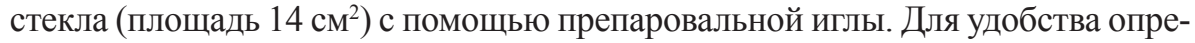
деления и учета остатков под предметное стекло подкладывали миллиметро-

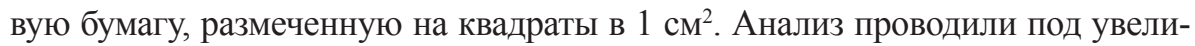
чением стереомикроскопа «Olympus SZ61» (Япония) и «МБС-10» (Россия).

Определение таксономической принадлежности остатков членистоногих проводили до отряда, а в отдельных случаях до семейства с помощью определителей $[2,14]$, а также путем сравнения с коллекцией насекомых, пой- 
манных с помощью светоловушки в месте отлова летучих мышей. С целью создания фотоколлекции остатков проводили фотографирование наиболее характерных элементов с помощью стереомикроскопа «Olympus SZ61»- изменение увеличения: 2x-4x (при фронтальной линзе 2х и окулярах 10x).

Для количественной оценки остатков рассчитывали встречаемость и обилие различных таксонов членистоногих. Относительная встречаемость доля проб, в которых обнаружены остатки представителей таксона, от общего числа проб (для каждой выборки отдельно) [4, 10]. Относительное обилие - доля квадратов (1 см²), в которых встречается данный таксон, от суммы квадратов для всех найденных таксонов (для каждой выборки отдельно) [4]. Количественный учет непосредственно остатков не производился ввиду их сильной измельченности. Всего проанализировано 80 проб. Из них 40 проб (7 особей) экскрементов за 11 июля и 40 проб (2 особи) за 16 июля. Математическую обработку данных проводили с использованием пакета программ StatSoft STATISTICA for Windows 6.0. и Excel.

\section{Результаты исследования и обсуждение}

Особенности определения фрагментов насекомых. В экскрементах двухцветного кожана нами отмечены остатки насекомых 8 отрядов: двукрылые, чешуекрылые, жесткокрылые, равнокрылые, ручейники, полужесткокрылые, сетчатокрылые, перепончатокрылые и представители подкласса паукообразных - клещи (таблица).

Размеры встречаемых остатков варьируют от $<0,1$ до 8 мм. По степени раздробленности и определяемости их можно разделить на три группы: 1) фрагменты размером менее 0,5 мм - наиболее часто встречаются, но плохо различимы, лишь в очень редких случаях можно точно сказать, к какому таксону принадлежит тот или иной элемент (например, чешуйки Lepidoptera); 2) фрагменты размером от 0,5 до 2 мм - подобного размерного класса элементы встречаются часто, но далеко не всегда с уверенностью можно определить, к какому семейству (или даже отряду) принадлежит часть насекомого такого размера; 3 ) фрагменты размером более 2 мм встречаются редко (не более 2-3 остатков на стекло), но они наиболее информативные для определения, почти всегда можно с уверенностью установить их систематическое положение (до семейства). Наиболее точное определение можно провести по конечностям насекомых, которые хорошо различаются для разных отрядов. Эффективно, если на фрагменте лапки сохраняются коготки и/ или «подушечка» (например, для Brachycera). Хорошим определительным признаком может служить наличие раздвоенных члеников на конечностях. Кроме того, определение остатков возможно по структуре крыльев. Так, в случае сохранности их фрагментов значение имеет расположение жилок. Даже по небольшому элементу крыла можно не только безошибочно установить наличие в пробах представителей отряда, но и определить, к какому 
семейству принадлежит фрагмент насекомого, пример - фрагменты крыльев сетчатокрылых. В пробах часто отмечаются чешуйки двукрылых и чешуекрылых, а также различного рода волоски и щетинки ручейников и короткоусых двукрылых. Однако, как правило, они отделяются во время прохождения по пищеварительной системе летучих мышей и лишь дополнительно к другим фрагментам указывают на присутствие в пробах представителей той или иной таксономической группы насекомых. Следует более подробно остановиться на описании фрагментов разных таксономических групп членистоногих, поедаемых двухцветными кожанами.

Перечень фрагментов членистоногих, обнаруженных

в экскрементах двухцветного кожана

[List of arthropod fragments found in the droppings of Parti-coloured bat]

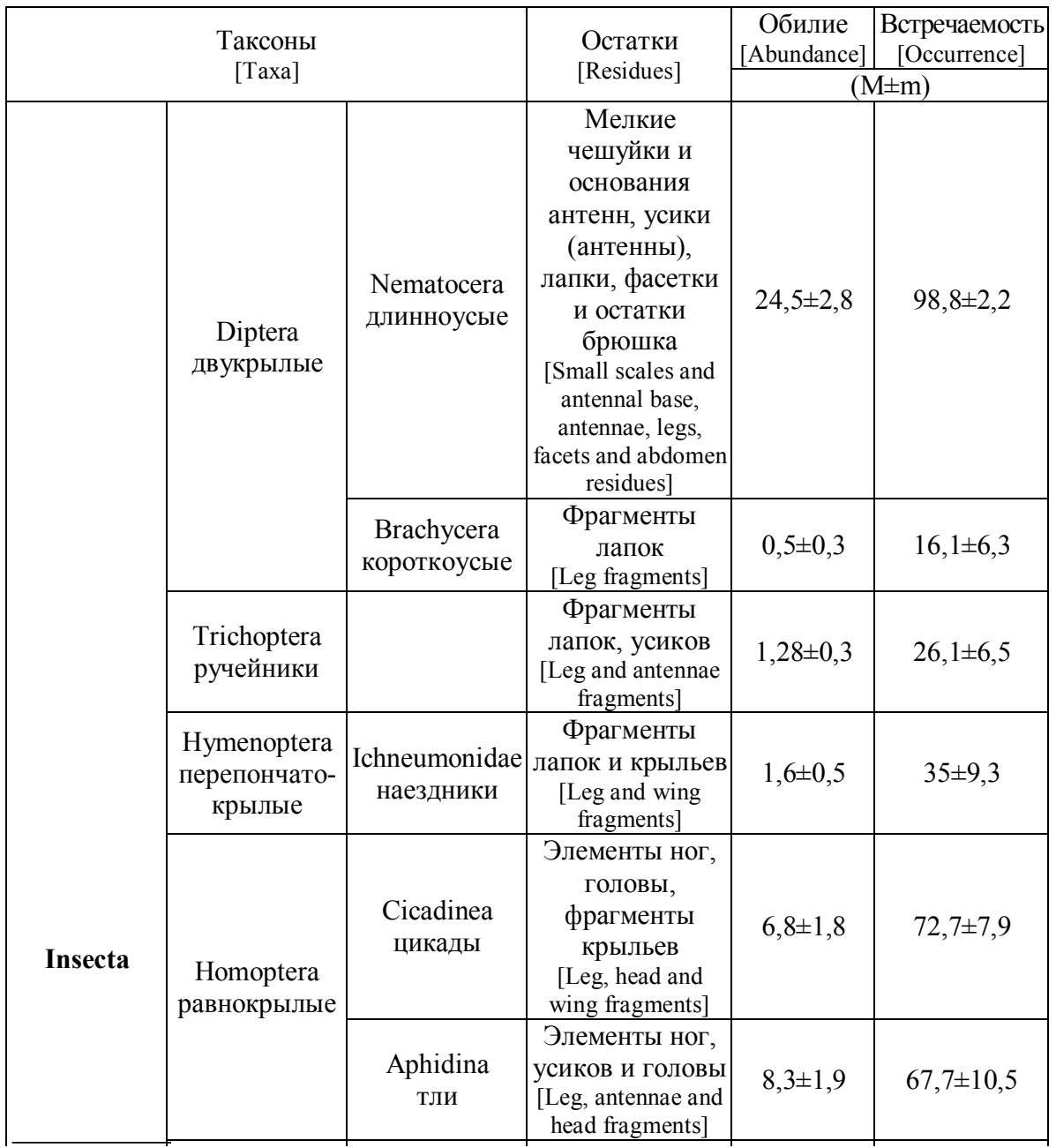


О к о н ч а н и е т а б ли цы [Table (end)]

\begin{tabular}{|c|c|c|c|c|c|}
\hline & $\mid \begin{array}{c}\text { Coleoptera } \\
\text { жесткокрылые }\end{array}$ & & $\begin{array}{c}\text { Фрагменты } \\
\text { лапок } \\
\text { и надкрыльев } \\
\text { [Leg and elytra } \\
\text { fragments] }\end{array}$ & $13,1 \pm 1,2$ & $95 \pm 4,4$ \\
\hline & $\mid \begin{array}{c}\text { Lepidoptera } \\
\text { чешуекрылые }\end{array}$ & & $\begin{array}{c}\text { Многочисленные } \\
\text { чешуйки, } \\
\text { элементы ног } \\
\text { [Numerous scales, } \\
\text { leg fragments] } \\
\end{array}$ & $2,4 \pm 0,6$ & $48,8 \pm 8,8$ \\
\hline & $\begin{array}{c}\text { Hemiptera } \\
\text { полужестк- } \\
\text { крылые }\end{array}$ & & $\begin{array}{c}\text { Элементы ног, } \\
\text { хоботки } \\
\text { [Leg fragments, } \\
\text { probosces] } \\
\end{array}$ & $3,9 \pm 1,2$ & $56,6 \pm 7,8$ \\
\hline & $\begin{array}{c}\text { Neuroptera } \\
\text { сетчатокрылые }\end{array}$ & $\begin{array}{c}\text { Hemerobiidae } \\
\text { гемеробы }\end{array}$ & $\begin{array}{c}\text { Фрагменты } \\
\text { крыльев, } \\
\text { усиков, ног } \\
\text { [Wing, antennae } \\
\text { and leg fragments] } \\
\end{array}$ & $5,1 \pm 1,0$ & $58,8 \pm 10,02$ \\
\hline & & $\begin{array}{l}\text { Chrysopidae } \\
\text { златоглазки }\end{array}$ & $\begin{array}{c}\text { Фрагменты } \\
\text { крыльев } \\
\text { [Wing fragments] }\end{array}$ & $0,8 \pm 0,4$ & $15 \pm 7,5$ \\
\hline Arachnida & $\begin{array}{c}\text { Acari } \\
\text { клещи }\end{array}$ & & $\begin{array}{c}\text { Целиком } \\
\text { [Entire] }\end{array}$ & $0,2 \pm 0,09$ & $11,1 \pm 4,8$ \\
\hline $\begin{array}{c}\text { Неопред. } \\
\text { остатки } \\
\text { [Unidentifie } \\
\text { d residues] }\end{array}$ & \begin{tabular}{|c|} 
Самые \\
разнообразные \\
[The most \\
diverse $]$
\end{tabular} & & & $30,9 \pm 1,9$ & 100 \\
\hline
\end{tabular}

Примечание. $(\mathrm{M} \pm \mathrm{m})$ - среднее арифметическое и его ошибка.

[Note. $(\mathrm{M} \pm \mathrm{m})$ - the arithmetic mean and the standard error of the mean].

Перепончатокрылые. В пробах фрагменты наездников хорошо выделяются, их конечности имеют два характерных зубчатых когтя, между которыми бывает «подушечка» (рис. $1, a)$. На крыльях жилок и ячеек немного; как правило, сохраняются волоски. Очень редко попадаются остатки крыльев с сильно хитинизированным пятном - крыловым глазком (рис. $1, b$ ). Членики четковидных усиков наездников имеют на поверхности продольные углубления (рис. $1, c$ ).

Двукрылые. Различать элементы насекомых этого отряда затруднительно. В целом фрагменты длинноусых и короткоусых двукрылых похожи. Для представителей отряда характерно своеобразное строение ротового аппарата с хоботком, на конце которого расположены утолщения - губные щупики. В пробах в большом количестве встречались мелкие чешуйки представителей длинноусых двукрылых семейства Culicidae и покрытые чешуйками фрагменты крыльев Chironomidae (рис. $1, d$ ). А также часто попадались сильно опушенные усики - антенны и их шарообразные основания, по которым определялись представители семейств Chironomidae и Ceratopogonidae (рис. 1, e, f). Фрагменты лапок короткоусых двукрылых определялись нами по наличию «подушечек» и характерному металлическому отблеску (рис. $1, g$ ). 


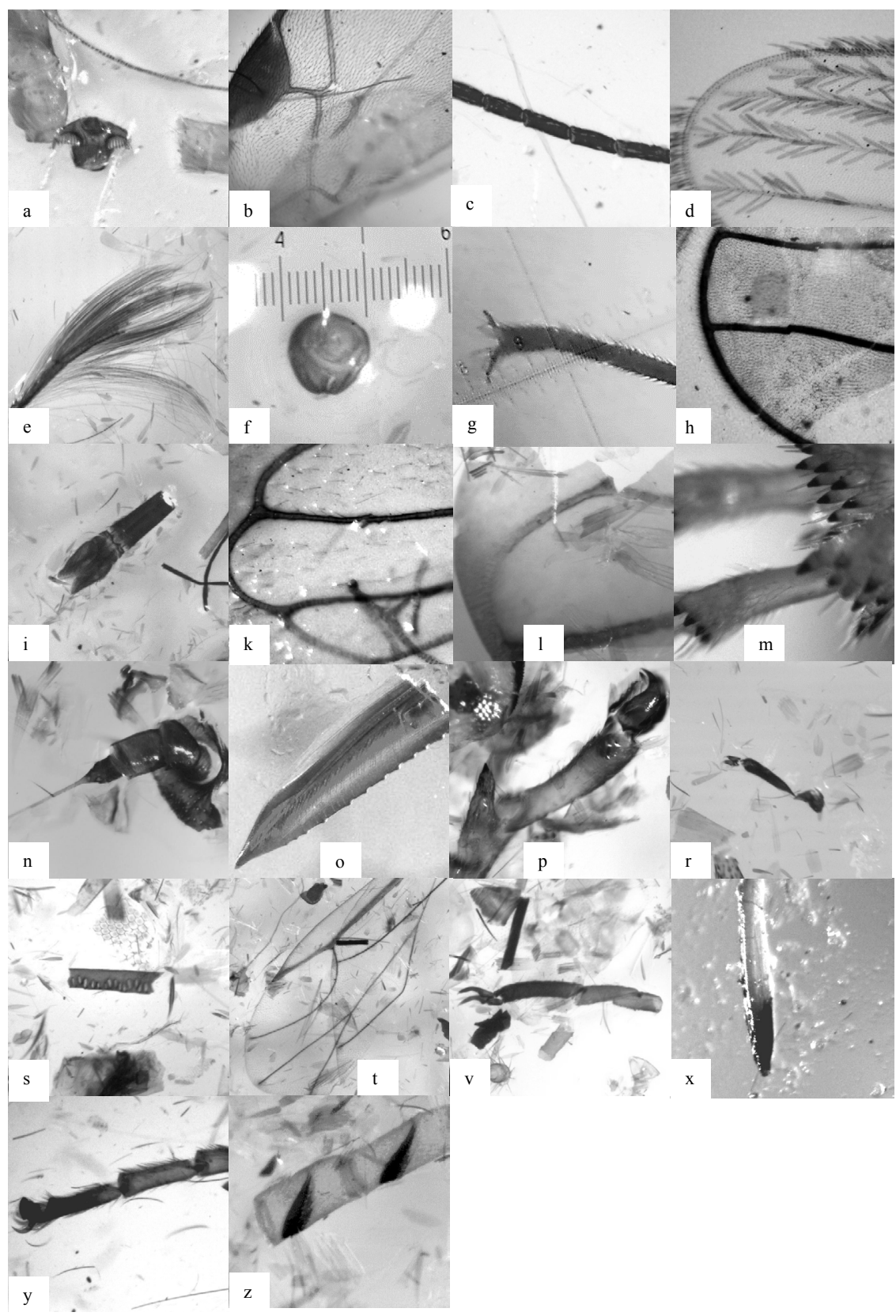

Рис. 1. Фотографии фрагментов членистоногих в экскрементах Vespertilio murinus: $a$ - нога наездника; $b$ - крыло наездника; $c$ - усик наездника; $d$ - крыло длинноусых двукрылых (Chironomidae); $e$ - усик длинноусых двукрылых (Chironomidae); $f$ - основание усика двукрылого; $g$ - лапка короткоусого двукрылого; $h$ - крыло короткоусого двукрылого; $i$ - губные щупики ротового аппарата короткоусого двукрылого; $k$ - крыло цикадовых с «псевдокраем»; $l$ - надкрылье цикадовых 
с вдавлениями; $m$ - фрагмент конечностей цикадовых с выростами; $n-$ фрагмент головы (усик) цикадовых; $o$ - фрагмент яйцеклада цикадовых; $p$ - лапка цикадовых; $r$ - лапка тли; $s$ - элемент усика тли с отверстиями; $t$ - крыло тли; $v$ - лапка клопа; $x$ хоботок клопа; $y$ - лапка ручейника; $z$ - часть усика ручейника (фото О.Р. Гизуллиной)

[Fig. 1. Photographs of arthropod fragments in Vespertilio murinus droppings: $a$ - leg of Ichneumons; $b$ - Wing of Ichneumons; $c$ - Antenna of Ichneumons; $d$ - Wing of Nematocera Diptera (Chironomidae); $e$ - Antenna of Nematocera Diptera (Chironomidae) $f$ - Antennal base of Diptera; $g$ - Leg of brachycera; $h$ - Wing of brachycera; $i$ - Labial palps (mouthparts) of Diptera; $k$ - Wing of Auchenorrhyncha with "false margin"; $l$ - Hemelytra of Auchenorrhyncha with depressions; $m$ - Leg fragments of Auchenorrhyncha with spines; $n$ - Fragment of the head (antenna) of Auchenorrhyncha; $o$ - Fragment of ovipositor of Auchenorrhyncha; $p$ - Leg of Auchenorrhyncha; $r$ - Leg of aphids; $s$ - Antennal fragments of aphids with holes; $t$ - Wing of aphids; $v$ - Leg of bug; $x$ - Proboscis of bug; $y$ - Leg of caddis; $z$ - Antennal fragment of caddis (photographs made by OR Gizullina)]

Остатки крыльев мух очень схожи с остатками крыльев длинноусых, но имеют большое количество жестких волосков и более темную окраску (рис. $1, h)$. Изредка попадаются фрагменты ротового аппарата мух (рис. $1, i)$.

Равнокрылые. Остатки этих насекомых достаточно четко различались по размеру и по структурным элементам до подотрядов - Cicadinea (цикадовые) и Aphidina (тли). На фрагментах передних крыльев цикадовых заметны утолщенные, преимущественно продольные жилки, иногда с образованием «псевдокрая» (рис. $1, k$ ). Остатки их более плотных надкрыльев имеют часто небольшие вдавления или отверстия на жилках (рис. 1, l). Встречаются также фрагменты мощных ног цикад, которые имеют характерные выросты - шипы или толстые щетинки, и широкие когти (рис. $1, m, p$ ). В пробах отмечаются редко усики (рис. $1, n)$ и остатки брюшка цикадовых (рис. $1, o$ ). По сравнению с цикадами фрагменты тлей более мелкие, их конечности очень тонкие с небольшими треугольными коготками (рис. 1, r). Попадаются фрагменты усиков тлей, у основания которых имеются поперечные овальные отверстия (рис. $1, s$ ). Крылья тлей часто попадаются цельные, они прозрачные с немногими жилками, на передних крыльях передняя жилка утолщена (рис. 1,t).

Полужесткокрылые. Фрагменты представителей этого отряда имеют сходство с равнокрылыми насекомыми. Но клопы хорошо определяются по остаткам лапок, которые имеют удлиненные членики и когти (рис. $1, v)$. Также в пробах мы часто находили острые кончики хоботков, характерные для колюще-сосущего ротового аппарата клопов (рис. $1, x$ ).

Ручейники. Определение представителей отряда в пробах затруднено ввиду недостаточной сохранности остатков. Более четко определить ручейников можно по фрагментам их ног, которые характеризуются наличием крупных жестких шпор на нижней поверхности голени (рис. 1, y). Наиболее характерный признак присутствия в пробе ручейников - это наличие базальных члеников усиков с темной полосой (рис. 1,z). 




Рис. 2. Фотографии фрагментов членистоногих в экскрементах Vespertilio murinus: $a$ - фрагмент надкрылья жука; $b$ - лапка жука (Chrysomeloidea); $c$ - усик жука (Chrysomelidae); $d$ - лапка водного жука; $e$ - лапка жука (Scarabaeidae); $f$ - усик жука (Scarabaeidae); $g$ - лапка жука (Carabidae); $h$ - усик жука (Carabidae); $i$ - чешуйки бабочек; $k$ - лапка бабочки, покрытая чешуйками; $l-$ фрагмент конечности бабочки с отверстиями для крепления чешуек; $m$ - хоботок бабочки; $n$ - сцепление передних и задних крыльев бабочек; $o$ - лапка сетчатокрылых

(Hemerobiidae); $p$ - лапка сетчатокрылых (Chrysopidae); $r$ - усики сетчатокрылых

(Hemerobiidae); $s$ - усик сетчатокрылых (Chrysopidae); $t$ - крыло сетчатокрылых (Hemerobiidae); $v$ - крыло сетчатокрылых (Chrysopidae); $x$ - клещ (фото О.Р. Гизуллиной) 
[Fig. 2. Photographs of arthropod fragments in Vespertilio murinus droppings: $a$ - Fragment of beetle elytra; $b$ - Leg of beetle (Chrysomeloidea); $c$ - Antenna of beetle (Chrysomelidae); $d$ - Leg of water beetle; $e$ - Leg of beetle ( Scarabaeidae); $f$ - Antenna of beetle (Scarabaeidae); $g$ - Leg of beetle (Carabidae); $h$ - Antenna of beetle (Carabidae); $i$ - Scales of butterflies; $k$ - Leg of butterfly, covered with scales; $l$ - Fragment of a butterfly limb with holes for fixing scales ; $m$ - Proboscis of butterfly; $n$ - Frenulum - wing-coupling device of butterflies; $o$ - Leg of lacewing (Hemerobiidae); $p$ - Leg of lacewing (Chrysopidae); $r$ - Antennal fragments of lacewing (Hemerobiidae); $s$ - Antenna of lacewing (Chrysopidae); $t$ - Wing fragment of lacewing (Hemerobiidae); $v$ - Wing of lacewing (Chrysopidae); $x$ - Mite (photographs made by OR Gizullina)]

Жесткокрылые. Остатки представителей этого отряда характеризуются сильной хитинизацией и жесткостью (рис. $2, a$ ). Определение фрагментов жуков в ряде случаев возможно до надсемейства и семейства. Принадлежность их остатков устанавливается в основном по форме члеников лапок и форме усиков. Например, присутствие в пробах представителей надсемейства Chrysomeloidea (сем. Chrysomelidae, Cerambycidae и другие) выявляли по наличию в пробах лапок с раздвоенным третьим члеником (рис. $2, b$ ). Также найдены фрагменты непосредственно сем. Chrysomelidae - тёмноокрашенные чётковидные усики (рис. 2, c). Фрагменты водных жуков (сем. Hydrophilidae, Dytiscidae, Haliplidae и др.) определялись по наличию в пробах задних плавательных ног, которые приплюснуты и снабжены, по крайней мере на внутренней стороне, длинными волосками (рис. $2, d$ ). Кроме того, в пробах обнаружены фрагменты пластинчатобулавых усиков и лапок представителей семейства Scarabaeidae (рис. 2, e, f) а также остатки бегательных ног и нитевидных усиков представителей Carabidae (рис. 2, g, h).

Чешуекрылые. В пробах обнаруживали большое количество отдельных чешуек бабочек (рис. 2, i). Само по себе присутствие чешуек в экскрементах не дает сведений о количественной оценке поедаемых насекомых, так как известно, что чешуйки бабочек сохраняются в кишечнике летучих мышей длительное время [3]. Следовательно, наличие чешуек свидетельствует о ранее съеденных представителях этого отряда. Поэтому в ходе анализа мы учитывали присутствие в пробах этой группы насекомых только при наличии каких-либо других остатков. Лапки и крылья чешуекрылых, как правило, хотя бы частично, сохраняют покрывавшие их чешуи (рис. $2, \kappa)$, в противном случае видны места их прикрепления в виде мелких отверстий (рис. 2, l). Сложно перепутать с чем-либо элементы сосущего ротового аппарата чешуекрылых (рис. $2, m$ ). Кроме того, в пробах часто отмечались остатки сцеплений передних и задних крыльев бабочек (рис. 2, n).

Cетчатокрылые. Отличаются от других отрядов насекомых своеобразным строением лапок, их когти расположены на значительном расстоянии друг от друга (рис. 2, o, p). В пробах попадались остатки представителей двух семейств - Hemerobiidae и Chrysopidae. Усики гемеробов обычно светлые и четковидные, отдельные членики усиков более короткие и широкие (рис. $2, r$ ) по сравнению со златоглазками (рис. 2, s). Определение представителей этих семейств возможно также по фрагментам крыльев, имеющим различия в жилковании (рис. $2, t, v)$. 
Помимо насекомых, в пробах отмечались очень мелкие экземпляры (менее 1 мм) клещей. Как правило, они обнаруживались не поврежденными (рис. $2, x$ ). Появление клещей в экскрементах, мы предполагаем, является следствием их эктопаразатизма на насекомых, поедаемых летучими мышами. Именно поэтому они не могут считаться пищевыми объектами и исключены из анализа.

Структура рациона двухцветного кожана. Из-за сильной измельченности и деформации фрагментов мы не всегда могли точно оценить обилие в пробах отдельных семейств, поэтому основные результаты по соотношению поедаемых видом членистоногих представлены, как правило, по отрядам, реже по подотрядам и семействам (см. таблицу). В связи с трудностью определения мелких элементов неопределенные остатки преобладают над всеми другими.

Как отмечено выше, для оценки количественных различий использованы два показателя - обилие и встречаемость. Несмотря на то, что диаметрально противоположных результатов с их помощью не выявлено, скорее наоборот, они оказались высоко согласованными между собой, каждый из них имеет свои нюансы. Если встречаемость могла быть отмечена как стопроцентная вне зависимости от числа найденных фрагментов даже если в какой-то конкретной пробе присутствовал всего один опознанный фрагмент представителей данного отряда, то обилие численно отражает соотношение конкретных пищевых групп насекомых в каждой выборке (см. таблицу).

Наиболее часто в рационе двухцветного кожана встречаются двукрылые (см. таблицу). Среди их остатков большинство принадлежит подотряду длинноусых двукрылых (комары) - в среднем 98,8\% встречаемости. Короткоусые двукрылые или мухи встречаются в меньшем количестве - 16,1\%. Конечно, последние не являются типично ночными насекомыми, но поскольку двухцветные кожаны охотятся на протяжении всей ночи, то возможно, что они ловят мух в сумерках, вылетая сразу после захода солнца или на рассвете, залетая в убежище. Кроме того, летучие мыши могут охотиться на насекомых, летающих около фонарей, в том числе прилетающих на свет ловушки в сумерках мух. В питании вида также часто встречаются жуки (95\%) и представители отряда равнокрылых (цикады) - 72,7\%.

Второй показатель - относительное обилие - показал явное доминирование тех же таксонов: длинноусые двукрылые $(24,5 \%)$, равнокрылые $(15,1 \%)$, жесткокрылые (13\%), которые вместе составляют более $3 / 4$ всего опознанного состава рациона вида. Частота обилия всех остальных отрядов насекомых, кроме сетчатокрылых (5,9\%), не превосходит пятипроцентный показатель. Таким образом, мы можем утверждать, что основой питания двухцветного кожана в изучаемом районе являются представители трех отрядов - двукрылые, равнокрылые и жесткокрылые. Удивляет низкий процент в изученных нами пробах обилия ручейников, которые в рационе вида, по данным других авторов, имеют важное значение [15]. Возможно, небольшое количество ручейников в пробах объясняется слабой дифференциацией 
их остатков. В дальнейшем накопленная нами определительная база позволит более точно различать ручейников среди других членистоногих. Кроме того, небольшие частоты обилия и встречаемости отмечены нами по перепончатокрылым (см. таблицу), и это можно объяснить тем, что, по некоторым данным, двухцветный кожан избегает есть представителей этого отряда при наличии альтернативного корма [12].

В целом наши результаты согласуются с данными других авторов, полученными на территории Европы (Швеция, Польша, Белоруссия) [15-17] и России [10]. Но имеются различия в количественном соотношении поедаемых видом таксонов членистоногих. Так, на территории Польши наиболее важным компонентом рациона двухцветного кожана считаются длинноусые двукрылые [15]. Сходны результаты на территории Швеции [17]. В отличие от наших данных, на второе место по значимости эти авторы определяют ручейников и чешуекрылых. В нашем случае почти такое же значение, как двукрылые, имеют представители отрядов равнокрылые и жуки, а ручейники имеют довольно скромные показатели. В питании вида на территории Польши равнокрылые, наоборот, представлены в относительно небольших объемах, хотя и с достаточно высокой частотой, особенно для тлей. Среди остальных компонентов питания, по данным польских исследователей [15], довольно большое значение имеют сетчатокрылые, главным образом семейство гемеробы (в нашем случае эта группа выходит на 4-е место), и жесткокрылые. Кроме того, на территории Польши в рационе двухцветного кожана присутствуют в небольшом количестве Psocoptera (сеноеды), Plecoptera (веснянки), Dermaptera (уховертки) и Ephemeroptera (поденки). Отсутствие этих насекомых в рационе вида в Среднем Зауралье, по-видимому, обусловлено временем проведения сбора экскрементов - это вторая половина лета, когда насекомые этих групп не образуют крупных скоплений в результате массового размножения и, следовательно, не поедаются летучими мышами.

Несколько отличаются от вышеописанных и наших данных сведения о питании вида на территории Белоруссии [16]. Согласно этому источнику, основу рациона составляют чешуекрылые и жуки, а также ручейники. Такие отряды, как двукрылые и сетчатокрылые, в питании вида не обнаружены. Сходные сведения получены на территории России в Самарской области [10]. Учитывая сказанное выше, структура рациона двухцветного кожана на указанных территориях России и Европы имеет общие черты. Описанные изменения в численном соотношении разных пищевых групп, на наш взгляд, обусловлены целым комплексом факторов и необязательно связаны с географическим положением мест сбора экскрементов.

\section{Заключение}

Как показали наши исследования, встречаемые в экскрементах двухцветного кожана фрагменты членистоногих имеют небольшие размеры, которые 
варьируют от $<0,1$ до 8 мм. В связи с трудностью определения мелких элементов неопределенные остатки преобладают над всеми другими. В условиях равнинного Среднего Зауралья в питании двухцветного кожана нами отмечены насекомые 8 отрядов: Diptera (Nematocera, Brachycera), Trichoptera, Hymenoptera (Ichneumonidae), Homoptera (Cicadinea, Aphidina), Coleoptera, Lepidoptera, Hemiptera, Neuroptera (Hemerobiidae, Chrysopidae). Наиболее часто и в большем количестве встречаются длинноусые двукрылые, жуки и равнокрылые (цикады). Наши данные в целом согласуются с данными по питанию вида, полученными другими авторами на территории Европы и России.

Выражаем глубокую признательность за помощь при сборе исследуемых материалов сотруднику Свердловского областного краеведческого музея в.н.с. А.А. Первушину, канд. биол. наук А.С. Влащенко (НИИ биологии ХНУ имени В.Н. Каразина) и д-ру биол. наук Д.Г. Смирнову (Пензенский государственный педагогический университет) за предоставленные литературные источники, необходимые для определения фрагментов насекомых.

\section{Литература}

1. Ботвинкин А.Д. Летучие мыши в Прибайкалье (биология, методы наблюдения, охрана). Иркутск : Время странствий, 2002. 208 с.

2. Shiel C., McAney C., Sullivan C., Fairley J. Identification of Arthropod Fragments in Bat Droppings. London : Mammal Society, 1997. 56 p.

3. Flavin D.A., Biggane S.S., Shiel C.B., Smiddy P., Fairley J.S. Analysis of diet of Daubenton's bat Myotis daubentonii in Ireland // Acta Theriologica. 2001. Vol. 46, № 1. P. 43-52.

4. Goiti U., Vecin P., Garin I., Salona M., Aihartza J.R. Diet and prey selection in Kuhl's pipistrelle Pipistrellus kuhlii (Chiroptera: Vespertilionidae) in south-western Europe // Acta Theriologica. 2003. Vol. 48, № 4. P. 457-468.

5. Williams C., Salter L., Jones G. The winter diet of the lesser horseshoe bat (Rhinolophus hipposideros) in Britain and Ireland // Hystrixlt. J. Mamm. (n.s.). 2011. Vol. 22, № 1. P. 159-166.

6. Long B.L., Kurta A., Clemans D.L. Analysis of DNA from feces to identify prey of Big Brown Bats (Eptesicus fuscus) caught in apple orchards // American Midland Naturalist. 2013. Vol. 170. P. 287-297.

7. Zeale M.R.K., Butlin R.K., Barker G.L.A., Lees D.C., Jones G. Taxon-specific PCR for DNA barcoding arthropod prey in bat faeces // Molecular Ecology Resources. 2011. Vol. 11. P. 236-244.

8. Борисенко А.В., Сесина Н.И., Закеева И.Р., Букия А.Н. К изучению трофической биологии трех видов рукокрылых (Chiroptera: Vespertilionidae) в Подмосковье // Plecotus et al. 1999. № 2. C. 36-43.

9. Никулин А.Д. Изменчивость кормодобывающего поведения рукокрылых (Chiroptera, Vespertilionidae) европейской части России // Plecotus et al. 2010. № 13. С. 44-47.

10. Смирнов Д.Г., Вехник В.П. Экология питания и дифференциация трофических ниш рукокрылых (Chiroptera: Vespertilionidae) в пойменных экосистемах Самарской Луки // Известия РАН. Серия биологическая. 2014. № 1. С. 53-64.

11. Казаков Д.В., Махов И.А. Питание сибирского ушана (Plecotus ognevi) в различного типа стациях в Байкальской Сибири // Известия Иркутского государственного университета. Серия «Биология. Экология». 2015. Т. 11. С. 32-42. 
12. Гизуллина O.P., Первушина E.M. Избирательность питания летучих мышей // Экология: популяция, вид, среда : матер. конф. молодых ученых, 14-18 апреля 2014 г. / ИЭРиЖ УрО РАН. Екатеринбург : Гощицкий, 2014. С. 13-16.

13. Колесников Б.П., Зубарева Р.С., Смолоногов Е.П. Лесорастительные условия и типы лесов Свердловской области. Свердловск : УНЦ АН СССР, 1974. 174 с.

14. Плавильщиков Н.Н. Определитель насекомых. М. : ГУПИМП РСФСР, 1950. 543 с.

15. Bauerova Z., Ruprecht A. Contribution to the knowledge of the trophic ecology of the particoloured bat, Vespertilio murinus // Folia zool. 1989. Vol. 38, № 2. P. 227-232.

16. Курсков А.Н. Рукокрылые Белоруссии. Минск : БелНИИНТИ, 1981. 135 с.

17. Rydell J. The diet of the parti-coloured bat Vespertilio murinus in Sweden // Ecography. 1992. № 15. P. 195-198.

Поступила в редакцию 06.06.2016 г.; повторно 02.08.2016 г.; принята 17.08.2016 г.; опубликована 21.09.2016 г.

\begin{abstract}
Авторский коллектив:
Гизуллина Олеся Рафаиловна - инженер-исследователь лаборатории популяционной экологии и моделирования Института экологии растений и животных УрО РАН (г. Екатеринбург, Россия). E-mail: gizullina_OR@ipae.uran.ru

Первушина Евгения Михайловна - канд. биол. наук, н.с. лаборатории популяционной экологии и моделирования Института экологии растений и животных УрО РАН (г. Екатеринбург, Россия). E-mail: pervushina@ipae.uran.ru

Gizullina OR, Pervushina EM. Determination of insect fragments in the diet of Vespertilio murinus in the Middle Trans-Urals. Vestnik Tomskogo gosudarstvennogo universiteta. Biologiya - Tomsk State University Journal of Biology. 2016;3(35):92-106. doi: 10.17223/19988591/35/6 In Russian, English summary

\section{Olesya R. Gizullina, Evgenia M. Pervushina}

Institute of Plant and Animal Ecology, Ural Division of the Russian Academy of Sciences, Yekaterinburg, Russian Federation

\section{Determination of insect fragments in the diet of Vespertilio murinus in the Middle Trans-Urals}

Studies of bats diet are of scientific and practical interest. But in the vast territory of Russia such studies are rare. Therefore, we study the diet structure of the background and highly plastic bat species in the Middle Urals - Vespertilio murinus (Linnaeus, 1758) (Chiroptera, Vespertilionidae). The aim of the research was to study the species diet structure and to create an atlas qualifier of prey fragments, using a digital stereo microscope.

We collected the material in Skorodumskoye village (Irbit district of Sverdlovsk region, $57^{\circ} 36^{\prime} \mathrm{N}, 62^{\circ} 52^{\prime} \mathrm{E}$ ) on the $11^{\text {th }}$ and $16^{\text {th }} \mathrm{July}, 2012$. We studied bat diet analyzing bat droppings. After collecting droppings, the bats were set free. In the laboratory, we selected 5-10 excrements of the close size and form for each individual. Each dropping (sample) was placed on a glass slide in a drop of glycerol. To determine and to count, the residues of arthropods were uniformly distributed on the glass surface $\left(14 \mathrm{~cm}^{2}\right.$ area), graph paper marked up into squares of $1 \mathrm{~cm}^{2}$ was placed under the slide. To create a photo collection of the residues we photographed the most characteristic elements, using the stereo microscope "Olympus SZ61" - 2x-4x magnification (2x front lens and $10 x$ eyepieces). Totally, 80 samples were analyzed. For quantitative estimation of the residues we calculated the relative occurrence and abundance of various arthropod taxa. 
The relative occurrence is the share of samples with the taxon residues in the total number of samples (for each individual). Relative abundance is the share of squares $\left(1 \mathrm{~cm}^{2}\right)$ with the taxon residues in the total number of squares of all found taxa (for each individual).

The paper describes fragments of arthropods eaten by $V$. murinus, and gives photos for identification. Fragments of arthropods found in the droppings were from $<0.1$ to 8 $\mathrm{mm}$. We identified limb and wing residues of insects most precisely which were specific in various orders. Indefinite residues predominated due to the difficulty to identify small elements. Basing on the results of the research on V. murinus diet in the plain of the Middle Trans-Urals we noted 8 orders of insects: Diptera (Nematocera, Brachycera), Trichoptera, Hymenoptera (Ichneumonidae), Homoptera (Cicadinea, Aphidina), Coleoptera, Lepidoptera, Hemiptera, Neuroptera (Hemerobiidae, Chrysopidae); and representatives of Arachnida (Acari). The most abundant and frequent were the following groups: Diptera (Nematocera) - 24.5\% abundance, $98.8 \%$ occurrence, Homoptera Homoptera (Cicadinea) - 15.1\% abundance, $72.7 \%$ occurrence, and Coleoptera $-13 \%$ abundance, $95 \%$ occurrence. Our data agree with the data obtained by other authors in Europe and Russia, but with differences in quantitative ratios of prey (arthropod) groups.

Funding: This work was partially supported by the Russian Foundation for Basic Research (Grant No 12-04-31257).

Acknowledgments: We express our deep gratitude to AA Pervushin (Sverdlovsk Regional Local Lore Museum, Yekaterinburg, Russia) for assistance in the collection of the material and Cand. Sci. (Biol.) AS Vlaschenko (Research Institute of Biology of VN Karazin Kharkiv National University, Charkiv, Ukraine) and Dr. Sci. (Biol.) DG Smirnov (Penza State Pedagogical University, Penza, Russia) for providing literary sources, necessary for determining insect fragments.

The article contains 2 Figures, 1 Table, 17 References.

Key words: bats; Vespertilio murinus; feeding.

\section{References}

1. Botvinkin AD. Letuchie myshi v Pribaykal'e (biologiya, metody nablyudeniya, okhrana) [Bats in the Baikal region (biology, methods of surveillance, security)]. Irkutsk: Vremya stranstviy Publ.; 2002. 208 p. In Russian

2. Shiel C, McAney C, Sullivan C, Fairley J. Identification of Arthropod Fragments in Bat Droppings. Occasional Publication of the Mammal Society. 1997;17:56

3. Flavin DA, Biggane SS, Shiel CB, Smiddy P, Fairley JS. Analysis of the diet of Daubenton's bat Myotis daubentonii in Ireland. Acta Theriologica. 2001;46:43-52. doi: 10.1007/ BF03192415

4. Goiti U, Vecin P, Garin I, Salona M, Aihartza JR. Diet and prey selection in Kuhl's pipistrelle Pipistrellus kuhlii (Chiroptera: Vespertilionidae) in south-western Europe. Acta Theriologica. 2003;48:457-468. doi: 10.1007/BF03192492

5. Williams C, Salter L, Jones G. The winter diet of the lesser horseshoe bat Rhinolophus hipposideros in Britain and Ireland. Hystrix. 2011;22(1):159-166. doi: 10.4404/ hystrix-22.1-4498

6. Long BL, Kurta A, Clemans DL. Analysis of DNA from feces to identify prey of Big Brown Bats (Eptesicus fuscus) caught in apple orchards. American Midland Naturalist. 2013;170:287-297. doi: 10.1674/0003-0031-170.2.287

7. Zeale MRK, Butlin RK, Barker GLA, Lees DC, Jones G. Taxon-specific PCR for DNA barcoding arthropod prey in bat faeces. Molecular Ecology Resources. 2011;11:236-244. doi:10.1111/j.1755-0998.2010.02920.x 
8. Borisenko AV, Sesina NI, Zakeeva IR, Bukiya AN. K izucheniyu troficheskoy biologii trekh vidov rukokrylykh (Chiroptera: Vespertilionidae) v Podmoskov'e [On studying the trophic biology of three bat species (Chiroptera: Vespertilionidae) in Moscow oblast]. Plecotus et al. 1999;2:36-43. In Russian

9. Nikulin AD. Variability of foraging behaviour of bats (Chiroptera, Vespertilionidae) in European part of Russia. Plecotus et al. 2010;13:44-47. In Russian, English summary

10. Smirnov DG, Vekhnik VP. Ecology of nutrition and differentiation of the trophic niches of bats (Chiroptera: Vespertilionidae) in floodplain ecosystems of the Samara Bend. Biology Bulletin. 2014;41(1):60-70. doi: 10.1134/S1062359014010105

11. Kazakov DV, Makhov IA. Diet of Plecotus ognevi in Various Types of Stations in the Baikalian Siberia. Izvestiya Irkutskogo gosudarstvennogo universiteta. Seriya «Biologiya. Ekologiya» - The Bulletin of Irkutsk State University. Series "Biology. Ecology". 2015;11:32-42. In Russian, English summary

12. Gizullina OR, Pervushina EM. Izbiratel'nost' pitaniya letuchikh myshey [Feeding selectivity of bats]. In: Ekologiya: populyatsiya, vid, sreda. Materialy konf. molodykh uchenykh [Ecology: population, species, environment. Proc. Conf. Young Scientists (Yekaterinburg, Russia, 14-18 April 2014)]. Yekaterinburg: Goshchitskii Publ.; 2014. pp. 13-16. In Russian

13. Kolesnikov BP, Zubareva RS, Smolonogov EP. Lesorastitel'nye usloviya i tipy lesov Sverdlovskoy oblasti [Forest growth conditions and forest types of Sverdlovsk region]. Sverdlovsk: Ural. Fil. Akad. Nauk SSSR Publ.; 1974. 174 p. In Russian

14. Plavil'shchikov NN. Opredelitel' nasekomykh [Insect indicator]. Moscow: UCPEDGIZ Publ.; 1950. 543 p. In Russian

15. Bauerova Z, Ruprecht A. Contribution to the knowledge of the trophic ecology of the particoloured bat, Vespertilio murinus. Folia Zoologica. 1989;38(2):227-232.

16. Kurskov AN. Rukokrylye Belorussii [Chiroptera of Belorussia]. Minsk: Nauka i Tekhnika Publ.; 1981. 135 p. In Russian

17. Rydell J. The diet of the parti-coloured bat Vespertilio murinus in Sweden. Ecography. 1992;15(2):195-198. doi:10.1111/j.1600-0587.1992.tb00024.x

Received 6 June 2016; Revised 2 August 2016; Accepted 17 August 2016; Published 21 September 2016

\footnotetext{
Author info:

Gizullina Olesya R, Research Engineer, Laboratory of Population Ecology and Modeling, Institute of Plant and Animal Ecology, Ural Branch of the Russian Academy of Sciences, 202a 8 March Str., Yekaterinburg 620130, Russian Federation.

E-mail: gizullina_OR@ipae.uran.ru

Pervushina Evgenia M, Cand. Sci. (Biol.), Researcher, Laboratory of Population Ecology and Modeling, Institute of Plant and Animal Ecology, Ural Branch of the Russian Academy of Sciences, 202a 8 March Str., Yekaterinburg 620130, Russian Federation.

E-mail: pervushina@ipae.uran.ru
} 